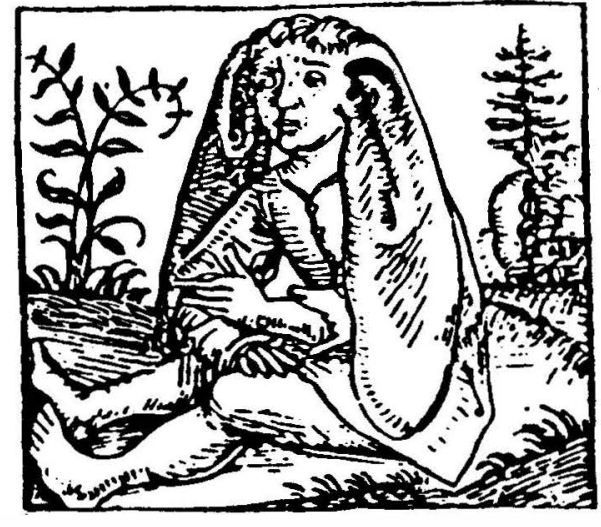

Panote

\title{
Litteraturteori i en post-Teoretisk tid
}

\author{
KaRen-Margrethe SimONSEN
}

Der findes i dag to historier om litteraturteoriens udvikling. Den ene historie er en radikal emancipationsfortælling, der hævder selve emancipationen fra emancipationstænkningen, den anden er en forfaldsmyte, historien om det tabte paradis.

Den første historie hævder, altid lettere polemisk og euforisk, at teorien er død. Vi er, som amerikanerne siger, "beyond theory". Efter i flere århundreder at have været domineret af metafysisk teori, kan vi nu endelig tage springet ud i en ny ikke-metafysisk metaforik og trække vejret frit. Vi kan leve ud fra vore kontingente, umiddelbare og institutionelle sammenhænge og ud fra små teoretiske refleksioner uden at blive irettesat af en kedelig, Teoretisk overbygning.

Den anden historie hævder, altid lettere polemisk og melankolsk, at teorien er død, dvs. den rigtige teori. For faktisk lever vi $i$ et hyperteoretisk univers. Men tidligere, i de gode gamle (germanske) dage, var litteraturteorien videnskabelig, fornuftig og tæt relateret til sit empiriske objekt, nemlig litteraturen. Dengang var teorien systematisk, sandhedssøgende og argumentativt ærlig. I dag er teorien usystematisk, selvtilstrækkelig, selvprofilerende og narcissistisk.

Hvad enten man vælger den første eller den anden historie har vi altså et udviklingsperspektiv, der postulerer den 'gamle' teoris død, og dermed lever vi i en post-Teoretisk tid. På den anden side ligger det også implicit i de to holdninger, at den teoretiske refleksion langt fra er ophørt. Den har blot, lykkeligt eller skandaløst, ændret karakter. Hvad enten man vælger den ene eller den anden historie, er forandringen irreversibel. 
Teorien er død i den forstand, at den ikke længere eksisterer som én entydig, magtfuld og ubetvivlelig størrelse. Det har den måske aldrig gjort, men udviklingen i det 20. århundrede har betydet en yderligere underminering af teoriens fundament. I Kritik, nr. 115, 1995 skriver Jens Erik Kristensen, at diskussionen om åndsvidenskaberne i det 19. århundrede hovedsageligt var fokuseret på grundlagsproblemet, som drejede sig om, hvorvidt åndsvidenskaberne var videnskabelige eller almentdannende, kritiske eller traditionsformidlende. ${ }^{1}$ Som J. E. Kristensen siger, er dette grundlagsproblem aldrig blevet løst. Og hvad mere er, vil jeg hævde, fundamentet for løsningen er yderligere blevet eroderet. Grundlagsproblemet er i dag blevet udvidet så meget og er blevet angrebet på så forskellig vis af så mange forskellige teoretiske retninger, at det ikke længere kan opridses som ét grundlagsproblem. J. E. Kristensens artikel giver selv en sober og udmærket opregning af de utroligt mangfoldige litteraturteoretiske tendenser i dette århundrede.

Denne mangfoldighed alene er den direkte årsag til Teoriens død. Ingen håber længere på en altoverskuende teoretisk platform, ingen håber længere at finde et helt ubetvivleligt fundament for den litterære refleksion, og endelig er der mange, der egentlig ikke ønsker at optræde som 'repræsentanter' for én teori. Mange litterater vil hellere bevæge sig rundt $i$ et teoretisk kombinationsfelt end tænke enkelte teorier stringent igennem. Man vil holde sin teoretiske horisont åben og ikke lukke den ved at vælge ét teoretisk perspektiv. I stedet for stærke Teorier har vi fået et netværk af teoretiske refleksioner

Denne udvikling skal ikke nødvendigvis begrædes, da den uden tvivl har gjort teoridannelsen mere fleksibel, men i kølvandet er også fulgt en teoretisk uoverskuelighed, der undertiden har fået visse kritikere til at tage afstand fra teori som sådan eller indskrænke den til et afsides hjørne af det litterære diskussionsfelt. Teorien angribes nu både fra videnskabeligt og fra æstetisk hold. De videnskabs-orienterede angriber teoriens vidtløftighed, dens abstrakthed, dens mangel på fodfæste i en empirisk verden og dens filosofisk-litterære anlæg. De æstetisk-orienterede angriber teorien for at være anti-litterær, dvs. for at fjerne sig for meget fra sit objekt, for at være orienteret mod sig selv og sin egen sammenhæng.

Således er teorien netop i sin udogmatiske, eksperimenterende udgave blevet trængt fra to sider og dette er paradoksalt nok sket samtidig med teoriens eksplosive vækst. Teoriens proliferation hænger tæt sammen med teoriens indre og ydre krisetilstand. Jo mere man stiller spørgsmålstegn ved teori - både teoriens berettigelse, formål og form - jo mere teori vil man akkumulere. Der er tilsyneladende ikke noget, vi kan sætte i stedet for teori. Vi vil blive ved med at fylde hullet ud efter den traditionelle Teori med mere teori.

Tager man et blik ud over det aktuelle teoretiske felt, vil man hurtigt opdage, at der ikke blot er tale om krusninger i overfladen på en ellers evident teoretisk underbygning, men at det drejer sig om en radikal stillen spørgsmålstegn ved alle grundlæggende litteraturteoretiske og litteraturanalytiske kategorier. Hvad er en litterær tekst?, hvad er en læser?, hvad er en kontekst? Selv disse basale spørgsmål kan ikke besvares entydigt. Kategorierne er ikke længere selvevidente. Selv om de nye teoriformer ser meget anti-teoretiske ud, er de alle et forsøg på at finde nye og fundamentale pejlepunkter i et oceanisk felt af teori. Lad mig give et par ikke-repræsentative og ikke-homogene eksempler på den nye teori, set ud fra de tre grundspørgsmål.

\section{Hvad er en litterær tekst?}

Mange af angrebene på teori tager udgangspunkt i forsvaret for den litterære primærtekst. „Tilbage til teksten!", råber man deklamerende og forudsætter dermed, at det er evident, hvad en tekst er og hvordan man kommer tilbage til den. Som jeg allerede har nævnt er det litterære tekstbegreb imidlertid blevet voldsomt udvidet i det 20. århundrede, dels af de modernistiske formeksperimenter, dels af den postmoderne metafiktivitet, der stiller spørgsmålstegn ved tekstens udsigelsesevne og ved de gængse genrenormer.

Mens den litterære tekst således er blevet hybridiseret indefra, har teorien ligeledes angrebet den udefra. Først og fremmest har problemet været overhovedet at fastslå, hvori litteraritet består. ${ }^{2}$ 
Hvad er litterært sprog? Hvori adskiller en litterær tekst sig fra andre tekster? Dekonstruktionen har beskæftiget sig med spørgsmålet på forskellig vis, og er nået frem til, at litterariteten består i en vis kompleksitetsgrad og bevidst mangel på tillid til sprogets referentialitet. Definitionerne er imidlertid ofte vage, og er mere karakteriseret ved at stille spørgsmålstegn ved begrebet litteraritet end ved at give nogle svar.

Strukturalismen og semiotikken har været med til at udvide det 'litterære' objekt, således at det nu synes at kunne indfanges i såkaldte objektive strukturer og former i den generelle betydningsdannelse. Litteraturen opfattes som en begribelig tegndannelse på linie med andre tegndannelser. Hermed er objektet blevet så udvidet, at det specifikt litterære til en vis grad er forsvundet.

Pragmatikken, og her tænker jeg på Stanley Fish, hævder polemisk, at litterariteten ikke eksisterer. Fish beviser dette i sit velkendte eksperiment, hvor han får en hel flok studerende til at analysere seks navne som et digt, uden de aner uråd om fælden. Hans pointe er, at der ikke findes noget definitorisk grundlag for litterariteten. Litterariteten opstår ud af den kontekst, vi befinder os i, ikke ud fra de tekster, vi læser. Hvis vi er i en kontekst, der byder os at opfatte noget som litterært, vil vi automatisk gøre det. ${ }^{3}$ Jeg vil vende tilbage til dette synspunkt.

Alle disse 'ældre' teoretiske retninger har konstant udfordret vores generelle tekstbegreb. Hertil er der nu kommet en ny udfordring, der truer med helt at få tekstbegrebet til at implodere. Jeg tænker på den såkaldte hypertekst, som måske ikke er teoretisk særligt velfunderet, men som spiller en væsentlig rolle i den teoretiske praksis. Lad mig opholde mig ved den et øjeblik. Hyperteksten som fænomen er, trods historiske forlæg, stærkt knyttet til især ét aspekt ved det nye informationssamfund, nemlig udbredelsen af computeren. Visse teoretikere ligestiller computerens indtog med Gutenberghus' revolution af trykketeknikken. En revolution, der påvirkede hele den litterære institution og dens indhold. Computeren er ikke et uskyldigt redskab, men ændrer hele vores holdning til vores objekt, nemlig den litterære tekst. Begrebet „hypertekst" anvendes både som betegnelse for denne ændrede tekstopfattelse og for en bestemt tekstype.

Som teksttype er hyperteksten grundlæggende en ikke-lineær tekst, hvis grænser altid står til debat. Ikke-lineariteten kan være indbygget $i$ teksten eller den kan indtræffe som en intervention fra kontekstens eller læserens side. Der finder en implicit eller eksplicit interaktion sted, der stiller spørgsmålstegn ved tekstens enhed og betydning. Computeren muliggør desuden, at teksten overskrider det rent skriftlige og benytter flere medier. I sig selv behøver dette ikke at rokke ved tekstbegrebet, så længe inddragelsen af billeder, grafik og lyd optræder som illustration af det, der i forvejen foregår i teksten. I hyperteksten er der imidlertid en tendens til at bruge de forskellige medier til en omfattende erodering af skriften.

Hyperteksten eksisterer i flere udfoldelsesgrader. Nogle teoretikere mener, at en teksts fodnotesystem i sig selv kan gøre den samlede tekst til hypertekst, idet læserytmen konstant brydes af de indskudte noter, hvilket skaber den karakteristiske ikke-linearitet. Et andet eksempel kunne være de CD-Rom'er, der behandler litterære klassikere, f.eks. Shakespeare: alle Shakespeares værker, et omfattende udvalg af tekstkommentarer, samt realoplysninger om samtiden findes her samlet og i et kompliceret samspil, der styres af de såkaldte links. Den mest radikale hypertekst er den tekst, der fra udgangspunktet er skabt som hypertekst $i$ en opsplittet form og ofte udnytter forskellige mediemuligheder.

Hvad enten, det nu drejer sig om den enkle eller den mere avancerede udgave, er det afgørende imidlertid, at hyperteksten ændrer tekstlæsningssituationen. I den hypertekstuelle verden sidder læseren ikke med en bog, men med et tekstudklip på skærmen. Alene dette faktum befordrer, at læseren ikke fokuserer på tekstens helhed, men på fragmenter af teksten. Manglen på stoflighed og materialitet ændrer tekstens påvirkning af læseren. Hertil kommer, at den måde, teksten fremtræder på på skærmen, i sig selv ikke opfordrer til læsning, men til behandling af teksten. Læseren er ikke læser, men bruger af teksten. 
I brugssituationen er det faktisk ikke primærteksten, der som selvberoende enhed er prioriteret højest, men dens aktiveringsmuligheder og dens kontekst og grænser. Læsningen er i hel konkret forstand ikke en passiv indoptagelse af skønhed og betydning, men en gøren: hvad kan man gøre med teksten, hvordan kan man situere den i forhold til de andre tekstfiler, hvordan kan den klippes, illustreres, flyttes rundt på etc. I det ovennævnte tilfælde, hvor teksten er hentet fra en CD-Rom med en litterær klassiker, vil der typisk være etableret et helt netværk af kontekstuelle links rundt om teksten, der på forskellig vis belyser den. Konteksten kan bestå i resten af forfatterens værker, der kan hentes ind som beskårne tekstbidder, ligestillet med primærteksten. Det kan være informationer om forfatterens liv, de litterære retninger, han/hun formodes at tilhøre, om samtiden og i det hele taget faktuelle, leksikonagtige opslag af ting, der kan være relevante for primærteksten. Således kan man i et digt om en bogfinke få fremkaldt et farvelagt billede af en bogfinke på skærmen, og oven i købet høre den pippe. Læserens opmærksomhed ledes konstant væk fra primærteksten, eller sagt på en anden måde: oplevelsen af primærteksten ændres konstant af de informationer og links, der inkalkuleres og som nødvendigvis må påvirke læseren.

I den hypertekstuelle læsning nedbrydes eller dekonstrueres således den tekstuelle enhed, og teksten diffunderer ud i et komplekst betydningsnetværk. Teksten er ikke længere en nærværende, selvevident æstetisk størrelse. Den har mistet autoritet og linearitet. Denne anti-metafysiske og tekstnedbrydende tendens i hyperteksten har fået en teoretiker som George P. Landow ${ }^{4}$ til at se hyperteksten som en logisk forlængelse af dekonstruktionen, og især af Derrida. Hvad er Derridas mærkværdige tekst Glas andet end en hypertekst? Glas er selve undermineringen af begrebet „bog". Teksten er delt op i spalter, der står over for hinanden og taler i munden på hinanden og dekonstruerer hinanden.

Der er imidlertid grund til at sætte spørgsmålstegn ved den direkte sammenkobling af hypertekst og dekonstruktion. Hyperteksten er nemlig langt mere enkel, målrettet og ukritisk i sit an- liggende end dekonstruktionen. I visse af hypertekstens former kan man se en direkte modarbejdning af dekonstruktionens selvbevidste marginalstrategier. Hyperteksten er både mere radikal og mere simpel end dekonstruktionen i sin brug af ikke-linære virkemidler.

Hertil kommer, at mange af de programmer, der er designede til hypertekstlæsning, stadigvæk er for uudviklede og har en tendens til at favorisere rimeligt naive læsninger. Den måde konteksten inddrages på i visse af programmerne kan være direkte irrelevant eller uinteressant, som f.eks. når dyre- og fuglearter præsenteres med billede og lyd, blot fordi disse optræder i det litterære værk. Måske er det netop ødelæggende for læsningen at vide, hvordan fuglen/dyret ser ud.

Mens man kan diskutere værdien af inddragelsen af visse former for kontekster i læsningen, er der imidlertid ikke tvivl om, at de, via deres præsentation på skærmen, skaber en grundlæggende brudsituation i læsningen. Konteksten inddrages ikke homogent, men heterogent og diskursfremmed i forhold til en normal linearitet. Den tekst, der fra starten bygger på ikke-linearitet radikaliserer disse brud i læsesituationen, men det er vigtigt at understrege, at der ikke nødvendigvis er tale om en 'chok'-effekt. Brudsituationen er så at sige almindeliggjort, den er ikke dramatisk, fremmedgørende eller overraskende. Som en anden teoretiker, Espen Aarseth, siger, kan chok-effekten kun fremkomme i en tekst, der egentlig bygger på normal linearitet. ${ }^{5}$ Eftersom hyperteksten grundlæggende bygger på ikke-linearitet er der ikke så meget tale om en enhed i krise, en enhed, der hele tiden dekonstrueres, men mere om at skabe forskellige muligheder for at konstruere en enhed. Teksten er fra starten et puslespil, der skal samles.

Den litterære tekst er derfor skrøbelig i betydningen altid foranderlig, den har mistet sin urørlighed. Dens litteraritet afhænger udadtil af den forhandling, der konstant foregår om dens grænser. Indadtil problematiseres dens litteraritet af dens sidestilling af et væld af forskelligartede tekster og dens sidestilling af forskellige medier, f.eks. tekst, lyd og billede. Over for denne krydsklippende, svært afgrænselige hybridtekst bliver spørgs- 
målet om, hvad en tekst er, og om, hvad litteraritet er, yderst akut og nærværende. Hyperteksten accentuerer et problem, der for så vidt altid har været til stede i litteraturteorien, men den gør det på en ny og uafviselig måde. Der er ikke blot tale om en teknisk set ny situation. Der er tale om en forandring af tekstbegrebet, og ikke mindst af vores interaktion med tekster. Her er der ingen nemme genveje til teksten i sig selv.

\section{Hvad er en læsning?}

Mens hyperteksten stiller spørgsmålstegn ved selve tekstbegrebet, flytter en anden af det tyvende århundredes væsentligste, litteraturteoretiske bevægelser opmærksomheden væk fra teksten og over mod læseren. Man taler om en re-hermeneutisering af litteraturteorien, en neopragmatisme og den såkaldte readerresponse kritik har udvidet sit indflydelsesområde betragteligt. Jeg kan på ingen måde yde retfærdighed over for dette store og meget nuancerede felt og vil blot knytte en kommentar til et enkelt problem, der rejses af hhv. hermeneutikken og pragmatikken.

Grundlæggende drejer diskussionen sig om forholdet mellem tekst og læsning: hvor meget betydning kommer fra teksten og hvor meget bibringes af læseren? finder læseren betydningen i teksten eller skaber læseren selv betydningen? og endelig: har dét, man finder, nogen sandhedsstatus eller er læsningen i sig selv en fritflydende, metaforisk tekst?

Trods hermeneutikkens lange og komplekse historie fra dens bibeleksegetiske oprindelse efter reformationen over det nittende århundredes hermeneutiske teorier af Schleiermacher og Dilthey til det tyvende århundredes udvidelse og revision af hermeneutikken hos Heidegger og Gadamer, bruges begrebet hermeneutik i dag ofte forsimplet og ofte med en negativ intonation med reference til en tematisering af kritikken; en tematisering, der vil bort fra en læsning af de retoriske lag $i$ teksten.

I hermeneutikken er der imidlertid, vil jeg hævde, taget filosofisk forbehold for en kortslutning mellem tekst og verden og dermed for en forsimplet forståelse af 'tematisme'. Det litterære værk er for hermeneutikeren en fortolkning, der åbenbarer en sandhed om verden. Denne sandhed kan ikke efterkontrolleres på verden, men kan kun diskuteres i forhold til andre fortolkningers sandheder. At sandheden ikke kan kontrolleres, gør den imidlertid ikke mindre sand. Den verdens- eller værensopfattelse, der optræder i vore fortolkninger, kan netop kun være sand. Netop fordi, den ikke kan efterprøves og dermed også udsætte sig for en falsifikationsmulighed, vil den sætte sig igennem som eksisterende og sand.

Der ligger i denne tilgangsvinkel et direkte anti-videnskabeligt anlæg, der åbner for en potentiel liberalisme i teorien. I dia$\log$ med teksten vil læseren finde frem til verdensforståelsen, men verden selv er aldrig objektiv, empirisk til stede, som den er i videnskaben. Som det er kendt, koncentrerer hermeneutikken sig om den cirkelbevægelse og samtale, der etableres mellem tekst og læser, og den interesserer sig mindre for relationen mellem værk og verden, en relation, der kun kan forstås gennem læseren. ${ }^{6}$ Når man polemisk hævder, at hermeneutikken er en retematisering af den litterære analyse, er det derfor en sandhed med i hvert fald filosofiske modifikationer. Selv om hermeneutikken vil stræbe efter forstålse af teksten, implicerer dette ikke en naiv, referentiel læsning.

Faktisk åbner hermeneutikken for en ikke-naiv tematisme, hvilket gør den egnet til en restituering i strukturalismens og dekonstruktionens formalistisk-retoriske kølvand. Hvor strukturalismen og dekonstruktionen engang var det kritiske opgør med en tradition, der var blevet overdreven metafysisk og litteraturkritisk set arbejdede tematisk naivt, så er disse teoretiske nyskabere nu selv og netop i kraft af den videnskabelige, kritiske sprogbevidsthed, paradoksalt blevet en del af den tradition, der skal gøres op med, eller som i det mindste skal forvindes. Hvordan kommer vi over eller forbi strukturalismen og dekonstruktionen? Ja, et bud er bl.a. at modernisere den tematiske læsning. Det er sikkert ikke muligt at overtage den hermeneutiske læsning, sådan som den er blevet overleveret. Men med en modernisering af hermeneutikken synes litteraturteorien at overvinde formalismen og skride ind i et nyt teoretisk felt. 
Til en vis grad kan man kalde pragmatikken en modernisering af hermeneutikken, og her tænker jeg især på Richard Rortys neopragmatik.7 Rorty har som én af sine vigtigste pointer en opprioritering af læserens rolle i betydningsdannelsen. Rorty er aldrig helt så radikal som Stanley Fish i denne henseende, men han er grundlæggende enig $i$ det filosofisk set umulige $i$ at fastslå tekstens egen mening. Teksten betyder ikke noget i sig selv. Rent litteraturteoretisk betyder dette, at man aldrig kan afgøre, hvilken læsning, der kommer tættest på teksten. Meningen, betydningen ligger ikke hvilende $\mathrm{i}$ teksten og venter på, at videnskabsmanden kommer og opdager den. Meningen skabes i et samspil mellem tekst og læser. Man kan ikke tænke betydning uden om læseren.

I forhold til hermeneutikken ligger der en radikalisering af denne holdning i pragmatikken. Den pragmatiske læser har en større frihed i dialogen mellem tekst og læser end den hermeneutiske læser. For hermeneutikken er forholdet mellem tekst og læser dualistisk: læser og tekst står over for hinanden i dialogsituationen. For pragmatikeren er forholdet mellem tekst og læser ikke dualistisk i denne forstand. Læseren har selv en lang forhistorie, der har dannet vedkommende, en forhistorie, der er skabt af en lang række konkrete og uigennemsigtige detaljer. Herudover er læseren medlem af en kultur, der består af et helt netværk af relationer. Når læseren læser, aktiveres hele dennes kontingente og idiosynkratiske personlige historie, og hele det kulturelle netværk, som subjektet er en del af.

Ud fra disse to 'determinanter' læser læseren en givet tekst ikke så meget i en dialogsituation, men i en situation af kontingent skabte relationer mellem særlige detaljer, der har konsekvenser både i teksten og for det læsende subjekt. Sagt på en anden måde, læseren læser arbitrært, stærkt udvælgende de detaljer, der har relevans for netop dette subjekt. I denne læsning skabes tekstens betydning, men mange vil også hævde, at den forvrænges, idet der ikke tages hensyn til tekstens betydningsmæssige enhed i sig selv, men kun til, hvad læseren kan få ud af at læse en givet tekst. Sagt på en anden måde, pragmatikeren har ikke så meget respekt for teksten som hermeneutikeren. Herme- neutikeren vil lytte til teksten, pragmatikeren vil bruge teksten. Heri ligger en konkret devaluering af tekstens autoritet og af tekstens såkaldte metafysiske nærvær og evne til at tale af sig selv. Læseren finder ikke, men skaber betydning. Hvad læseren kan få ud af en tekst bestemmes imidlertid bl.a. af hans eller hendes kontekst.

\section{Hvad er en kontekst?}

Kontekstbegrebet er et af den slags begreber, der ikke kan defineres endegyldigt. Det afhænger for sin definition selv af en kontekst, dvs. en teoridannelse, der giver det en bestemt drejning. Lad mig igen give et par eksempler.

For dekonstruktionen er konteksten altid tekstuel. Konteksten er i bogstavelig forstand en kon-tekst, dvs. en med-tekst. Konteksten er den eller de tekster, der får lov at tale i munden på den tekst, man nu læser. Man kan i dekonstruktionen ikke forestille sig ikke-tekstuelle kontekster. Konteksten er og vil altid blive inddraget i den generelle skriftproblematik og i det dekonstruktive tekstarbejde.

Anderledes ser det ud for pragmatikken. Stanley Fish taler om fortolkningsfællesskabernes kontekst, om forforståelser og om fordomme. Fokus er flyttet fra den tekstuelle kontekst til læserens egen kontekst, der ifølge Stanley Fish konstituerer teksten. Kontekst-begrebet henviser direkte til den sammenhæng, teksten læses i og ikke den sammenhæng, teksten er produceret i. Læserens psykologiske beredskab, hans forventningsstrukturer og hans institutionelle situation udgør tekstens reelle og aktuelle kontekst.

Richard Rorty arbejder, som nævnt, ikke helt så radikalt som Stanley Fish, men opretholder som denne ideen om, at læserens idiosynkratiske fordomme er med til at skabe teksten eller er med til at kontekstualisere teksten. Teksten ligger der som en afsluttet og for så vidt uforanderlig enhed, men den pragmatiske læser vil tendere mod ikke at respektere denne enhed, idet der ikke er noget interessant at sige om denne enhed i sig selv. Den pragmatiske læser, i rortysk forstand, vil tendere mod at lave læsninger, der udefra vil se overfortolkende og paranoide ud. 
Der er imidlertid ingen videnskabelige kriterier, der kan afgøre, hvor paranoid læsningen er, dvs. hvor tæt eller hvor fjernt man er fra teksten. Derfor burde man, ifølge Rorty, helt opgive tæthedskriteriet som sådant. Ligeledes burde man opgive at skelne mellem forskellige genretyper og i det hele taget en såkaldt videnskabelig kategorisering af livet.

For pragmatikeren er der ingen interessant forskel mellem „protoner og digte“. Der er ingen interessant forskel mellem "dinosaurer, ferskner, babyer og metaforer“. Det er der ikke, for vi vil altid agere ens over for alt; vi vil, uanset objektets art, bruge det. Brugsaspektet er det eneste gældende kriterium og dette åbner for en meget fri kontekstualiseringsmulighed. Læseren er fri til at placere teksten i den kontekst, han måtte finde inspirerende for sin egen brug. Hovedsynspunktet er, at teksten ikke selv beder om en bestemt type kontekstualisering.

Det ville være metafysisk og dermed uacceptabelt at antage, at f.eks. forfatterens liv og det samtidige samfund udgør den rigtige og nære kontekst for værket. At argumentere for dette ville typisk kræve en essentialistisk tænkning, der på den ene side skulle definere begrebet ",kunst“ og på den anden side begrebet "liv“" eller "samfund" og derefter forklare de to essentielle enheders rangforhold eller dualistiske forholden sig til hinanden.

Pragmatikken ville mene, at det er unødvendigt med denne favorisering af de traditionelle kontekster. Hyppigt er netop disse kontekster de mest uinteressante, og dermed er de faktisk diskvalificerede. Som Jonathan Culler har sagt det: det drejer sig ikke om at stille de spørgsmål, teksten lægger op til, det drejer sig om at stille de mindst oplagte spørgsmål. Det drejer sig om at overfortolke, dvs. at finde nye og spændende kontekster. ${ }^{8}$

Hvordan ser disse kontekstmuligheder ud i praksis? Hvis vi for eksempel tager Wordsworth' digtning: Hvilken kontekst er den mest interessante for denne digtning? Den traditionelle litteraturteori vil umiddelbart læse digtningen i forhold til den litteraturhistoriske periode, $\mathrm{i}$ forhold til de stilistiske særtræk i romantikkens digtning, romantikkens åndelige og samfundsmæssige bevægelser og i forhold til Wordsworth' livs specifikke vilkår, hans opvækst og uddannelse, hans sociale klasse og eventuelle kriser og problemer.

Den dekonstruktive læsning ville inddrage en anden tekst som kontekst. Det kunne være f.eks. Miltons Paradise Lost, som hele Wordsworth' forfatterskab skrives op imod både i en længsel efter at overgå Milton, og dermed "begå fadermord“, som Harold Bloom ville sige, og med en erkendelse af umuligheden af dette. Milton indskrives og opbrydes på forskellig vis i Wordsworth' eget forfatterskab. Gennem en nærlæsning af forfatterskabet vil dekonstruktionen vise, hvordan teksterne brydes med hinanden i et intertekstuelt spil, der kører bag om ryggen på forfatteren, men som sætter sig igennem i forskellige metaforvalg etc. Hermed vises forskellenes uendelige differeren i en kontekst af generaliseret skrift. ${ }^{9}$

Stanley Fish' pragmatiske læsning vil se på de institutionaliserede fordomme om hhv. digte, romantik og evt. Wordsworth, som læseren måtte have med sig.

Rortys pragmatiske læsning vil ikke følge et på forhånd fastlagt mønster, men derimod tage udgangspunkt i den konkrete læsers specifikke og private idiosynkrasier. Læseren holder f.eks. af farven rød og har en særlig svaghed for hunde og i det hele taget domesticerede dyr. På den anden side synes læseren generelt, at naturbeskrivelser er kedelige. Hvordan vil en sådan læser læse Wordsworth? Han vil læse fragmentarisk, ud fra de detaljer, han synes er interessante og de kontekster, der kan belyse dem. Han vil måske tage udgangspunkt i de situationer, hvor der dukker hunde op i Wordsworth, han vil måske interessere sig for de metaforer, der kondenserer spændingen mellem natur og kultur, han vil måske indsætte farvemetaforikken $\mathrm{i}$ et epistemologisk mønster, der så senere kan inddrages som sammenligningsgrundlag for farvemetaforikken hos Proust etc. Mulighederne er uendelige og det eneste kriterie er, om disse frie kontekster forekommer læseren frugtbare. Og her må man give Stanley Fish en indrømmelse: det er nemlig set ud fra den institutionelle kontekst, læseren befinder sig $i$, langt fra alle kontekster, der synes at være interessante eller frugtbare. Der er ingen principiel, men 
derimod en pragmatisk binding på kontekstualiseringsmulighederne.

\section{Nyhistorisme og kulturstudier}

Mens det teoretiske landskab på den ene side synes at favorisere en sådan fri kontekstualisering som pragmatikken lægger op til, er der også modsatrettede tendenser i landskabet, som vil forsøge at fastholde en vis logik og objektivitet i kontekstualiseringen. Dette gælder delvist den meget omfattende New Historicism, det gælder en voksende tendens til biografisme og det gælder de meget udskældte kulturstudier (cultural studies), der til dels er en udløber af New Historicism.

Nyhistorismen, som den må hedde på dansk, er et tohovedet fænomen, der både rummer en poststrukturalistisk og en politisk, social side. Stephen Greenblatt, som tilsyneladende er ophavsmand til begrebet, foreslår, at den befinder sig mellem poststrukturalisme og marxisme. Alene denne dobbelte bestemmelse antyder den komplekse kontekstualiseringsmulighed, der ligger i nyhistorismen.

Denne mulighed kan anskuliggøres med et kort blik på diskursanalysen, som er en central analysestrategi hos hovedinspiratoren, Michel Foucault. Diskursanalysen er en analyse eller en beskrivelse af den måde diskurserne arbejder med og mod hinanden $i$ et givet samfund. Det drejer sig om en meget nuanceret og forgrenet beskrivelsesmodel, der arbejder anti-hermeneutisk $i$ den forstand, at den ikke vil beskæftige sig med en fortolkning af tekster, men netop med en beskrivelse af teksternes funktionsmåde. Det drejer sig ikke om en eksistentiel dybdeforståelse, men om at se teksterne som diskursive kludetæpper. Diskursanalysen er et studium af selve sammensyningen af kludene, eller af det sammensatte mønster, kludene danner. Ikke hvad mønsteret betyder, men hvordan det er dannet. Der er to niveauer i analysen: dels beskrives grænserne mellem diskurserne, dels beskrives de enkelte diskurser i deres indre sammenhæng eller snarere deres indre diskontinuitet.

I denne beskrivelse forudsætter Foucault, ligesom dekonstruktionen, at alle kontekster er tekstuelle. Hertil kommer, at disse kontekster ikke er uskyldige, men indgår $\mathrm{i}$ et gensidigt magtspil, - en slags kontekst-konkurrence. Teksten selv, det der i et givet tilfælde betragtes som en primærtekst, er selv kommet til syne ikke bare på trods af magtstrukturerne, men også i kraft af dem. Der ligger i enhver teksts tilsynekomst en udelukkelse og undertrykkelse af andre diskurser. Således træder enhver tekst frem diskontinuert og i en grundlæggende brudsituation med de omgivende kontekstuelle diskurser. Konteksten er dermed ikke en homogen forklaring på teksten, men er ligeså meget et negativt udgangspunkt for teksten. Det drejer sig ikke bare om, at teksten er et opgør med traditionens kontekst. Det drejer sig mere om se et helt netværk af komplicerede kontekstrelationer, som teksten er afhængig af. Internt i teksten vil brudsituationen optræde som forskellige forbud eller tabuer og huller i teksten.

Nyhistorismens kontekstinddragelse tilstræber objektivitet, og metoden kan til en vis grad siges at være videnskabelig, men ikke i traditionel forstand. Nyhistorismen er en forskydning af gammel-historismen i den forstand, at den ikke har tillid til konteksterne som en forklaring på 'primærteksterne'. Der er rokket ved årsag-virkningsforholdet og ved selve muligheden af at komme til en endelig afklaring af en diskurs' grænser. Selv om diskursanalysen opfatter sig selv som beskrivende og ikke som fortolkende, så er beskrivelsen aldrig neutral (den må nødvendigvis selv være besat af magtforhold og tabuer), og det beskrevne objekt vil altid kunne forskydes ved internt at 'opdage' nye diskontinuiteter eller eksternt ved at inddrage nye kontekster, eller nye brud, i den beskrevne kontekst. Derfor er nyhistorismen kun næsten videnskabelig. Arven fra poststrukturalismen har betydet en indbygget skepsis over for den videnskabelige sandhed per se.

Med nyhistorismen er det igen blevet legitimt at inddrage samfundet i litteraturstudiet. Rent litteraturteoretisk har dette betydet en åbning mod det tematiske felt i litteraturen, men i nyhistorismen altid forstået som tekstbundet, og dermed kun tilgængeligt gennem en gennemgribende tekst-analyse.

Anderledes ser det ud i kulturstudierne, som findes i utroligt mange varianter helt fra den meget nuancerede kulturkritik til 
den politisk korrekte ideologisering af litteraturteorien. Fænomenet er hovedsageligt amerikansk og skyldes først og fremmest den mangfoldighed af kulturer, der er repræsenterede i USA. Der er ikke længere en enhedslig kultur, der kan assimilere de mindre. Den amerikanske kultur er snarere en konstant magtkamp mellem forskellige kulturfællesskaber. I den sammenhæng er det logisk, at det kan virke 'kriminelt' at glemme den kulturelle og samfundsmæssige kontekst for litteraturen. At bilde sig ind, at man skriver om det litterære eller det æstetiske, grænser til kulturchauvinistisk naivitet. For hvad har kulturliberalismen vist os andet, end at åndsprodukterne har deres direkte forudsætning i den kultur, de udspringer af. Således viser Edward Said i en nuanceret fremstilling, at vestens primitive begreb om orientalisme bunder i en kulturel fordom, der har været nødvendig for at skabe vestens billede af sig selv som en forfinet højkultur.

Kulturstudiernes væsentlige bidrag til litteraturteorien har, for det første, været en detronisering af den litterære kanon og en voldsom udvidelse af det litterære objekt, en udvidelse, der både er kulturel og geografisk. For det andet betyder kulturstudiernes inddragelse af kontekster, at ingen teoretiker umiddelbart kan indtage et neutralt, universelt udgangspunkt. Teorier dannes, som litterære værker, i det kulturelt bestemte møde med verdens andetheder. På en helt konkret og kontant måde destabiliseres den teoretiske objektivitet.

Mens nyhistorismen er bundet til tekstlæsningen, er kulturstudierne forpligtet over for den generelle, kulturelle og ikke nødvendigvis tekstualiserede situation. Det er imidlertid oplagt, at både nyhistorismen og kulturkritikken har store muligheder for at forny den tematiske kritik og forholdet mellem teori og praksis radikalt. Deres forskellige måder at inddrage kontekster på overskrider langt, hvad den tidligere litteraturhistoriske og den politiske ideologikritiske tradition kunne byde på. Men det må også understreges, at begge retninger rummer samme farer, som tidligere tiders forsøg på historiske og kulturelle læsninger, nemlig faren for en overdrivelse af de kulturelle forklaringsmønstre, faren for at teorien bliver reduktiv.
Nyhistorismen og kulturstudierne er, set i sammenhæng, udtryk for en og samme udvikling. Det er en udvikling, der tilsyneladende baserer sig på en mangelsituation og et forsøg på at genetablere kulturelle fundamenter. Efter at historien er imploderet, efter at kulturen er blevet så polyfon, at den ikke længere er selvfølgeligt og umiddelbart til stede, efter at alle er blevet immigranter eller pendlere i verdensgeografien, efter at subjektet har mistet sin immanente styrke og samlingskraft, har teorien forsøgt at genetablere en historie, en kultur, en geografi og et subjekt $i$ en eller anden form. De nye teoretiske retninger kan umiddelbart ses som en forsvarsmekanisme i forhold til informationssamfundets opløsende tendenser, samtidig med at de er udtryk for disse.

I vurderingen af nyhistorisme og kulturstudier vil netop spørgsmålet om deres forhold til tradition og samtid være afgørende: vil de to teoriretninger få litteraturteorien til at vende tilbage til traditionelle, tematiske læsninger, eller vil de udvikle de tematiske læsninger og dermed medvirke til en overskridelse af den postmodernisme, der er knyttet til en vis epoke i informationssamfundet? Det kan vi endnu ikke vide.

Én af de ting, der peger i retning af en reel fornyelse af litteraturteorien, er den stærkt voksende tværfaglighed, der eksisterer på de humanistiske studier. Denne tværfaglighed kan ikke blot bremses eller sættes i stå, men vil langsomt ændre humanisternes selvforståelse. Mens litteraturfaget tidligere kun havde filologien og sprogfagene (og filosofien) som søsterfag, ser man nu et udvidet samarbejde, f.eks. med de andre æstetiske fag, men også med historie, etnografi, psykologi, teologi og idehistorie. Måske endda med geografi, jura og de naturvidenskabelige fag. ${ }^{10}$ Tværfagligheden arbejder på mange forskellige niveauer, helt fra ren og skær inspiration til konkret samarbejde om tekster, seminarer etc.

Under alle omstændigheder er det ikke bare litteraturteorien, der står til debat, men også litteraturfagligheden. 


\section{Netværksteori}

Det teoretiske felt er ikke bare stort og næsten uoverskueligt, det er tillige et utroligt differentieret og problemfyldt område. ${ }^{11}$ Feltets mangfoldighed, mener jeg, afspejler stor interesse for de grundlæggende spørgsmål vedrørende tekst, læsning og kontekst. Ingen af spørgsmålene har indlysende svar, hvilket viser, i hvor høj grad teorien er i krise, men også i hvor høj grad teoretisk refleksion er nødvendig.

I den verserende debat hører man af og til det synspunkt, at teori er overflødig eller intetsigende i forhold til læsningen af den litterære tekst. Tværtimod vil jeg mene, at teorien er uundgåelig, hvis man vil forstå, hvad en læsning er. Simpelthen at læse teksten uden refleksion over, hvad man gør, er ikke muligt i en litteraturhistorisk og litteraturvidenskabelig institution. At læse tematisk, at læse retorisk, at læse biografisk, at læse litteraturhistorisk er alle teoretiske valg, man gør. Der findes ingen læsning, der ikke har teoretiske implikationer. Og der findes ingen læsning, der, teoretisk set, kommer tættere på teksten end andre. Derfor bliver man nødt til at diskutere teorien også ud fra teoriens eget grundlag. Dette betyder ikke, at man behøver at gribe til en stor teori-bygning, hver gang man skal læse en tekst, men det betyder, at der må være et minimum af teoretisk refleksion i enhver beskæftigelse med tekster.

Det tyvende århundredes teoretiske udvikling har sat spørgsmålstegn ved teoriens oprindelige formål og funktionsmåde. Udviklingen er ikke reversibel. Vi kan ikke have samme tillid til teoriens videnskabelighed eller til det skønne teoretiske system, som man kunne for blot hundrede år siden. Især efter strukturalismen og dekonstruktionen er der åbnet for et sandt overflødighedshorn af teoretiske muligheder. Vi taler ikke længere blot mod traditionen. Vi står ikke som avantgarden, og til dels dekonstruktionen oppositionelt over for én stor tradition. Vi befinder os snarere i et omskifteligt netværk af teoretiske refleksioner. I dette netværk tilhører man sjældent én bestemt skole, men kombinerer istedet elementer fra forskellige teorier, der i sig selv er under stadig forandring. Fagligheden er ofte tværfaglig. Heri ligger et helt paradigmeskift. Det drejer sig ikke så meget om, at nogle bestemte teorier er blevet skiftet ud med nogle andre. Det er i højere grad selve grundlaget for den teoretiske refleksion, der er ændret. Det drejer sig ikke om „Bildung durch Wissenschaft", som Humboldt ville det. Videnskaben er ikke et middel, men et af de grundlæggende problemer.

De meget forskelligartede teorier tager alle tager udgangspunkt i teoriens principielle krise. Men man kunne mene, at det kun er en vis form for teori, der er i krise. Der er en bestemt type teoriopfattelse, der ikke længere er plausibel. Men dette betyder ikke nødvendigvis, at teorien som sådan er overflødig. Hvad er teorien andet end en refleksion over, hvad man laver? Og hvordan kan man og hvorfor skulle man undgå, at denne refleksion påvirker ens litterære aktivitet? 


\section{Noter}

1. Jens Erik Kristensen: „Den kultiverede mumlen”, p. 43-53 i Kritik 115,1995

2. Der er selvfølgelig ikke noget nyt $i$ at diskutere, hvad litteraritet er. Det nye består mere i den radikalitet, der lægges for dagen i tilnærmelsen til spørgsmålet. Litteraturen placerer sig end ikke naturligt ind i et generelt accepteret æstetisk område. Litterariteten er principiel åben og kan diskuteres i forhold til lingvistik, filosofi, sociologi, psykologi etc.

3. Stanley Fish: Is There a Text in This Class, Cambridge, Massachusetts, 1980. Se specielt kapitlet: „How to Recognize a Poem When You See One".

4. George P. Landow: Hypertext. The Convergence of Contemporary Critical Theory and Technology, Johns Hopkins Univ. Press, Baltimore and London, 1992

5. p. $67 \mathrm{i}$ „Nonlinearity and Literary Theory" i Hyper/Text/Theory, ed. G. P. Landow, Baltimore \& London 1994. Aarseth påpeger, at begrebet hypertekst bruges på tre forskellige måder: som et generelt begreb til at beskrive ikke-linearitet, som benævnelse for en bestemt type computersystem og som et navn for en tekst, der findes i et sådant system.

6. Som Heidegger siger, sker der i læsningen følgende: et spørgsmå stilles til teksten, der derefter i en dybere forstand stiller et spørgsmål til læseren. Herved etableres den hermeneutiske cirkel. Denne cirkel har også tidligere været formuleret som en bevægelse mellem værk og tradition og som en bevægelse mellem værkets dele og værkets helhed. alle tre tilfælde drejer det sig imidlertid om en cirkelbevægelse, der udvikles gennem dialog og fortolkning, ikke om et uden videre videnskabeligt, forklarligt og objektivt forhold.

7. Se især Consequences of Pragmatism, Univ. of Minnesota Press $1982 \mathrm{og}$ Contingency, irony, and solidarity, Cambridge Univ. Press 1989

8. Jonathan Culler: „In defence of overinterpretation“ i Umberto Eco. Interpretation and overinterpretation, ed. Stefan Collini, Cambridge Univ. Press, 1992

9. Jeg beder læseren bære over med den skematisme, der ligger i denne skildring af den dekonstruktive læsning og af de læsninger, der følger Jeg har tilladt mig den grove forenkling af hensyn til profileringen af en bestemt problemstilling

10. Den tværfaglige relation mellem litteratur og jura kendes især fra USA. Stanley Fish, der er professor i engelsk, underviser på jurastudiet ved Duke University, hvor hans teorier om fortolkning, om manglen på fri talemulighed og fri vilje etc. åbenbart er direkte relevante. Den tværfaglige interesse for geografi og litteratur er stadig i sit gryende stadie. Interessen har sikkert udviklet sig under indtryk af kulturstudiernes generelle udvidelse af den geografiske horisont og opmærksomhed på stedet som medbestemmende kulturel faktor. Interessen har mange ansigter fra en helt konkret interesse for eksotiske landskaber til en interesse for rejsen og landskabet som metaforiske gestaltninger af det fremmede. Rent litteraturteoretisk kan inddragelsen af det geografiske element måske betyde en fornyet debat om realismen og eventuelt en forøget interesse for den amerikanske økologiske kritik, der baserer sig på en topografisk miljøbevidsthed.

11. Mange nyere tendenser har jeg måttet undlade. F.eks. nyere psykoanalytisk litteraturteori og semiotik, retorik og filologi (som i halvfemserne har taget en helt anden drejning end firsernes æstetiske interesse for retorik), samt en fornyet interesse for selvbiografiske og etiske læsninger. 